UDC 331:658.015

JEL Classification: D21, J24, J53, M12, 015

DOI: $10.15587 / 2312-8372.2019 .176842$

Voloshyna 5 .

\title{
DEVELOPMENT OF A CONCEPTUAL MODEL OF ADAPTIVE MANAGEMENT OF HUMAN CAPITAL REPRODUCTION OF INDUSTRIAL ENTERPRISES
}

Об'єктом дослідження є адаптивне управління відтворенням людського капіталу промислових підприємств. Встановлено, що управління відтворенням людського капіталу українських промислових підприємств характеризується комплексом проблем. Серед них - тривале відставання від світових рівнів витрат на робочу силу, що призводить до розриву у характеристиках людського капіталу, гіпертурбулентність середовища господарювання. Визначено, що відсутність наукових досліджень в галузі адаптивного управління відтворенням людського капіталу посилює глибину існуючих практичних проблем і унеможливлює формування в крайні інновачійної економіки. Це потребувало формування концептуальної моделі відповідного управління.

Доведено доцільність формування адаптивного управління за характеристиками адаптацї при удосконаленні ї̈ змістовного визначення. Принциповими аспектами нової конструкцї поняття «адаптація» $є$ : безперервність змін, процес як діяльність, взаємодія середовища господарювання і системи, реагування на зміни загального середовища, закладення в результат активної і пасивної поведінки підприємств, стратегічний контекст адаптивних змін. За ознакою реакиії і часу ї̈ здійснення виділено основні типи адаптивних процесів.

Визначено елементи адаптивного управління: сигнал, зміна, управлінський иякл, результат управління. На основі інтеграції цих елементів і змістовного контексту системи управління відтворенням людського капіталу проведено конструювання поняття «адаптивне управління відтворенням людського капіталу промислових підприємств». Визначено етапи такого управління та їх завдання. Сформовано схему концептуальної моделі адаптивного управління відтворенням людського капіталу промислових підприємств.

На підставі формальної оцінки структури і логіки побудови моделі, ї̈ істотних властивостей і зв'язків зроблено висновок про верифікащію моделі.

Реалізачія на практиці розроблених пропозицій дозволяє забезпечити швидку та адресну реакцію підприємств на зміни у середовищі господарювання стосовно коригування характеристик людського капіталу. На відміну від аналогічних відомих моделей запропонований формат створює підгрунтя для визначення адекватних напрямків трансформації відтворювального процесу.

Ключові слова: відтворення людсъкого капіталу, адаптивне управління, управлінський цикл, результат управління, конщептуальна модель.

\section{Introduction}

Recognition by the world in the second half of the XX century theory of human capital as the economic base of human development has made fundamental changes in approaches to state, industry, regional and company management and has formed global goals for the further development of the international community.

The current problems of the human capital reproduction in Ukraine, the manifestation of which is a significant natural and mechanical loss of its carriers, the extremely low motivation of workers, the unsatisfactory quality of working life, etc. led to the formation of persistent negative trends. Of particular threat are the problems that are being acquired at industrial enterprises, which form the basis of the entire national economy. It is in industry that the bulk of the country's GDP is created (according to $2017-21.7 \%$ ) and a significant part of the economically active population is concentrated. In 2017, industrial enterprises provided jobs for $12.6 \%$ of the working population or for $37 \%$ of the total employed population of the country [1].

Despite the structural changes that are now taking place objectively in the global economy in connection with the spread of the knowledge economy, the Ukrainian industry will remain the driver of the country's socio-economic development. However, the development of science-intensive industries in the future, the complications and dynamism of the state of the state grant radically change the requirements for the human capital of industrial enterprises and the conditions for its reproduction. This actualizes the task of managing the human capital reproduction of industrial enterprises with its transformation into adaptive management. 


\section{The object of research and its technological audit}

The object of research is the adaptive management of the human capital reproduction of industrial enterprises. It is a flexible transformation of management approaches based on the constant adjustment of tasks, structure and activities that counteracts the negative impact of environmental factors of enterprise management, characterized by extreme complexity, uncertainty and hyperturbulence.

The problems of the current stage of human capital reproduction management of a significant number of Ukrainian enterprises are related to:

- a significant lag in Ukrainian industry in terms of costs

for the reproduction of labor from world standards, which results in a gap in the characteristics of human capital; - uncertainty of the prospects for investing in the human capital of industrial enterprises will lead in the future to an increase in such a gap and a further increase in problems with the formation of personnel and the results of its use; - increase in the dynamics of changes in all segments of the business environment with the spread of globalization of the world economy, which requires changes in approaches to the general and functional management of enterprises.

Given the objective need for the formation of an innovative economy (knowledge economy) in Ukraine, overcoming the problems noted and achieving social progress cannot bypass the process of flexible (adaptive) management of the human capital reproduction.

\section{The aim and objectives of research}

The aim of research is the formation of a conceptual model of adaptive management of the human capital reproduction of industrial enterprises. To achieve this aim, it is necessary to complete the following objectives:

1. To determine the essence of the concept of «adaptive management of the human capital reproduction of industrial enterprises».

2. To substantiate the main elements of the conceptual model of adaptive management of the human capital reproduction of industrial enterprises and to establish functional relationships between them.

3. To verify the conceptual model with its essential features (verification).

\section{Research of existing solutions of the problem}

Acquaintance with scientific research and publications of the second half of the XX century - beginning of the XXI century shows a significant interest in the subject area of adaptive enterprise management. The directions of the research carried out mainly concern the issues of general enterprise management and, to a lesser extent, innovative development, economic security, competitiveness, potential, etc. At the same time, scientists single-handedly address the problems of managing the human capital reproduction without delving into the issue of adaptive management.

So, in [2], the theoretical and methodological foundations of managing the human capital reproduction are developed and a harmonized model of financial management is developed. However, this position is based only on the valuation of human capital, reduces the potential for managerial decisions and focuses primarily on the market value of the enterprise.

The work [3, 4] is devoted to the fundamentals and principles of managing the human capital reproduction in the context of ensuring its competitiveness, however, the main proposals of the author are declarative in nature.

According to the author of work [4], adaptive management is an innovative approach to management, which means the development of strategic alternatives based on the criterion of maximizing efficiency. Meanwhile, the main result of the study is reduced by this scientist to the adaptation of staff to new tasks in the organization's development, which cannot be equated to the creation of complete conditions for the organization's readiness to change its environment.

In $[5,6]$, in which the basic questions of the theory of organization are revealed, an adaptive model of the organization's development based on its adaptation to uncertainty conditions is formed. The authors of these works focused on passive adaptation, in which the organization defended itself. Whereas the option of interaction or a tidy environment for the needs of the organization is not considered, which in the current competitive markets does not meet the potential of the modern business to counter external threats. Therefore, the important question is how to structure the analysis of environmental factors that affect the result of the organization's activity, in particular parts of the human capital reproduction.

The authors of $[7,8]$ consider the organization in the system of a multidimensional space of resources and capabilities, which indicates a wide maneuver in its behavior. However, scientists consider the main cause of changes in the organization to be solely due to external factors. At the same time, they characterized the internal environment for a high degree of conservatism, which grows with an increase in the size of the organization and accumulated experience.

In [9], the task of creating a methodological basis for adaptive management of industrial corporations based on the development of models for their interaction with partners is solved from the same standpoint and is one of the aspects of active adaptation.

In $[10,11]$, among the many problems of the modern theory of organization, the importance of studying both internal and external development factors that are in constant motion and at the same time is both drivers of change and the cause of problems in making managerial decisions is noted. Such a statement of the scientific problem should be transferred to the study of key factors in the development of an enterprise, among which is human capital.

So, the effective and stable functioning of the management system for the human capital reproduction of industrial enterprises in the presence of unresolved scientific and practical problems of its provision objectively requires the development of a conceptual approach to determining:

- flexible (adaptive) nature of the interaction of its basic elements with each other and with the external environment;

- stages of the management cycle, their content and the like.

\section{Methods of research}

The research methodology is based on the principles of organization theory, systems theory, management theory, strategic management theory, human capital theory. 
The research results are based on the application of general scientific and special methods:

- systematic approach to the terminological analysis method - for constructing the concept of «adaptive management of the human capital reproduction of industrial enterprises»;

- theoretical and analytical modeling - to determine the elements of the conceptual model and its verification; - analysis, synthesis, comparison, generalization - to establish scientific gaps in the study, evaluate the results of the study, formulate conclusions;

- graphical way of presenting information - to visualize the research results.

\section{Research results}

In a general understanding, the conceptual model (from Latin Concertio - understanding, system and Latin Modulus - sample, norm) provides «a formal representation of the problem area at a conceptual level». It is characterized as «an abstract model that determines the structure of the object under study, the properties of its constituent parts, cause-effect relationships». In another version, it is «a strategic research plan that contains theoretical and methodological approaches, research problems, conceptual apparatus, hypotheses, data collection techniques» [12].

First of all, let's pay attention to the basic concepts of this subject area, which are substantiated by the author in $[13,14]$. Thus, the expediency of considering the «human capital of an enterprise as a set of processes that are systematically carried out within the life cycle of an enterprise and associated with the formation, use, professional and social development, restoration (preservation) of human capital or its disposal for the acquisition of characteristics by the elements of this capital has been proved necessary to create all participants in economic relations of additional benefit in any form» [13]. While the management system for the human capital reproduction of an enterprise is defined as «preparation and implementation, using analytical technologies and economic models of management decisions to ensure the formation and use of human capital to acquire elements of its characteristics that are necessary for the enterprise to achieve relevant economic and human development goals» [14].

The definition of an adaptive approach to managing the human capital reproduction of industrial enterprises requires a terminological analysis of the closely related concepts of «adaptation» and «adaptability» (Table 1). In general, both terms are interdisciplinary in nature, since they are objects of study of biology, psychology, sociology, technology, economics and other disciplines and are used to characterize economic, social and other types of systems and change their behavior. Meanwhile, each of the terms has features in the combination of constituent elements, which are determined by the essential feature and the expected result of the changes.

Table 1 shows that under the adaptation of most scientists and research teams understand:

- interaction of the system with the external environment; - process of its adaptation to changes in this environment; - process of converting the system to new conditions;

- reaction to changes in the environment;

- integration with the transmission of environmental signals.
Adaptation results are defined as:

- achieving equilibrium between the system and the external environment;

- coordination of the requirements of the participants in the relationship;

- adjustment of system parameters under the influence

of external changes;

- achieving compliance with new environmental con-

ditions through the goals of the activity;

- optimal behavior;

- creation of a mechanism for adaptation;

- adequacy of changes in the situation and the current state and the like.

Table 1

The results of the terminological analysis of the concepts of «adaptation» and «adaptability"

\begin{tabular}{|c|l|l|l|}
\hline Source & \multicolumn{2}{|c|}{ Essential feature } & Expected result of changes \\
\hline \multicolumn{3}{|c|}{ "Adaptation" concept } \\
\hline$[12]$ & $\begin{array}{l}\text { interaction with the environment; } \\
\text { compliance status; adaptations } \\
\text { to conditions; addiction process; } \\
\text { adaptation to real conditions; } \\
\text { adaptation to changing conditions }\end{array}$ & $\begin{array}{l}\text { system and the environment; } \\
\text { compliance with new conditions } \\
\text { of existence; compliance with new } \\
\text { environmental conditions }\end{array}$ \\
\hline$[15]$ & $\begin{array}{l}\text { ability of the system to modify } \\
\text { itself and the environment; reac- } \\
\text { tion to changes in the environment }\end{array}$ & $\begin{array}{l}\text { information recovery, preser- } \\
\text { vation and increase of system } \\
\text { efficiency }\end{array}$ \\
\hline$[16]$ & $\begin{array}{l}\text { signal integration and transmis- } \\
\text { sion property }\end{array}$ & new company behavior \\
\hline$[17]$ & $\begin{array}{l}\text { expectations and response to ex- } \\
\text { ternal stimuli }\end{array}$ & targeted changes \\
\hline$[18]$ & $\begin{array}{l}\text { process of transforming relation- } \\
\text { ships and relationships }\end{array}$ & not determined \\
\hline$[19]$ & help assess conditions & creation of adaptation mechanism \\
\hline$[20]$ & $\begin{array}{l}\text { change in the current state of the } \\
\text { enterprise }\end{array}$ & $\begin{array}{l}\text { adequacy of changes in the situ- } \\
\text { ation and current state }\end{array}$ \\
\hline & \multicolumn{1}{|c|}{ "Adaptability" concept } \\
\hline$[12]$ & $\begin{array}{l}\text { ability to adapt to changes in the } \\
\text { environment; functioning purpose- } \\
\text { ful system }\end{array}$ & $\begin{array}{l}\text { compliance with new environ- } \\
\text { mental conditions; consistency of } \\
\text { goals and performance }\end{array}$ \\
\hline$[21]$ & ability, opportunity and motivation & strategic thinking and action \\
\hline$[19]$ & property of power centers & reordering \\
\hline$[22]$ & ability and willingness to respond & leveling external threats \\
\hline
\end{tabular}

Particularly noteworthy is the position of the author of the work [15] on investing in the content of adaptation of the need to simultaneously respond to internal and external changes, while most scientists note only external changes. It is understandable that internal changes are predominantly manageable. But meanwhile, the internal environment is not devoid of the influence of unpredictable factors, which are called non-systemic risk factors, and in the study of human capital - social risk factors, which should be paid special attention.

Let's believe that social risks should be understood as the occurrence of adverse social events for enterprises, which indirectly lead to economic losses. The main carrier of social risks is workers as carriers of human capital. Mostly the causes of social risks are:

- low level of staff qualifications;

- staff turnover, which exceeds its natural level;

- low level of production discipline;

- occurrence of accidents;

- deterioration of the psychological climate in the team, etc. 
Given these reasons, it can be argued that the sources of social risk education are concentrated mainly in managerial activities and related to management problems, including:

- imperfect personnel policies;

- lack, insufficiency, inaccuracy of information and its concealment;

- low corporate culture;

- incorrect assessment of the capabilities and efforts of employees, their interest in the results of the enterprise;

- unsatisfactory psychological climate in the team, etc.

At the same time, social risks can arise under the influence of environmental factors, such as housing conditions, family relationships, family incomes, living standards in the country, political stability and the like.

Regarding the set of adaptation results, which can be traced according to the Table 1, let's consider it expedient to collapse them to two:

1) adaptation for maintaining efficiency or ensuring survival;

2) adaptation for improving efficiency or ensure development.

In turn, the «adaptability» concept in rare cases is equivalent to adaptation as a process of change. In most cases, it is considered as a property of the system by its ability, ability and correctness to change under the influence of changes in the external environment. In addition, the results of adaptability practically coincide with the results of adaptation.

Let's pay special attention to the principled position in this issue of the developer of the theory of strategic management of I. Ansoff. He invested a strategic context for understanding adaptability, which means that adaptation to environmental changes must occur in accordance with the strategic orientation of the enterprise [21].

Thus, in the context of the formation of adaptive management of the human capital reproduction of industrial enterprises, which acts as a process or targeted action, it is more appropriate to consider «adaptation» as the basic concept, and the concept of «adaptability» to determine the properties of a control system.

It should be noted that many scientists study adaptability not autonomously, but in conjunction with such properties of the economic system as:

- flexibility (quick response to any changes in economic activity);

- competition (the desire to best meet the needs of consumers);

- effectiveness (achieving a positive result);

- stability (maintaining the achieved result), etc. [15, 16]

This circumstance determines the logic of expanding the traditional understanding of adaptation and adaptability.

Based on the above, let's offer the author's wording of the term «adaptation» in the following construction. Adaptation is a continuous process of mutual adaptation and transformation of system parameters to changes in the general environment of the enterprise to ensure survival or development, corresponding to the strategic objective of its effective functioning.

Let's pay attention to the fundamental aspects of this definition:

1) duration or continuity of the change process;

2) process as an activity, during which new properties of the object of study are formed;

3) prediction of the possibility of interaction between the business environment and the system;
4) response to changes in the internal and external environment, taking into account factors of unsystematic risk, in particular social risks;

5) presentation of the results of adaptation as ensuring survival or development with verification of compliance with the requirements of effective functioning;

6) strategic context of adaptive change.

Modern scientists, in particular, the authors of [9, 23], define the two-fold task of adaptation as ensuring the mandatory and quick response of enterprise management to the influence of environmental factors. So, the main aspects of adaptive behavior can be considered: the action (reaction) and the time of its implementation. On this basis, it is advisable to distinguish the following main types of adaptive processes:

1) prediction of controlled changes, which leads to the possibility of a quick reaction when they occur;

2) prediction of uncontrollable changes and their exclusion from the number of objects in respect of which management decisions are made;

3) management of changes that are aimed at maintaining the current strengths of the enterprise and the formation of new ones.

There is a mixed opinion in the scientific community regarding the full or partial equating of adaptation to adaptive management. In particular, this can be seen in the definition of adaptation in [17], the authors of which consider it as a process of deliberate change of a certain object.

The development of scientific achievements, the authors of which substantively investigated the essence of adaptive control, shows differences in its characteristics with various details of such elements. This is confirmed by the difference in the key signs of differentiation of this concept (Table 2).

Table 2

Comparative assessment of scientific views on the concept of «adaptive management» by the key sign of differentiation

\begin{tabular}{|c|l|}
\hline Source & \multicolumn{1}{|c|}{ Key sign of differentiation } \\
\hline$[12]$ & $\begin{array}{l}\text { adaptation to unknown external and internal conditions and goal } \\
\text { achievement; controlled influences in conditions of uncertainty } \\
\text { and dynamism of system properties; determination of the desired } \\
\text { state of the system based on previous experience; research and } \\
\text { study environment }\end{array}$ \\
\hline$[24]$ & creation of a multi-purpose system \\
\hline$[25]$ & fine-tuning the organizational structure and management system \\
\hline$[26]$ & ensuring the effective functioning of the facility in new situations \\
\hline$[9]$ & $\begin{array}{l}\text { activities for monitoring and fixing deviations in the general en- } \\
\text { vironment, regulation and control, as well as activity in ensuring } \\
\text { system stability }\end{array}$ \\
\hline$[27]$ & $\begin{array}{l}\text { application of forms and methods that add flexibility to the ma- } \\
\text { nagement system }\end{array}$ \\
\hline$[28]$ & $\begin{array}{l}\text { process of making and implementing managerial decisions in the } \\
\text { context of a complex environmental impact and alternative behavior }\end{array}$ \\
\hline$[23]$ & $\begin{array}{l}\text { passive and active adaptation and determination of the corre- } \\
\text { sponding direction of development }\end{array}$ \\
\hline$[29]$ & \begin{tabular}{l} 
development of a non-stationary and changing strategy \\
\hline
\end{tabular}
\end{tabular}

Structural analysis of the «adaptive management» concept according to Table 2 shows that its main elements are:

- change in economic conditions (to new or indefinite, with or without division into internal and external); - management action, presented either as a general controlled influence or structured as the adoption and implementation of management decisions; 
- result (or goal as the end result) of adaptive control, which has both concretized and «fuzzy» formulations (achievement of the system's goal, desired state, effective functioning, internal stability), as a result of which there will be a problem of its formalization.

In the presented versions of the statement of results, only the consequences of passive adaptation with adaptation to changing conditions, including through the improvement of activities, are traced. The option of results when the system can affect the environment (active adaptation) is not considered.

Separately, it should be noted that there is a lack of scientific research on adaptive management of the human capital reproduction in general and the human capital of industrial enterprises in particular. In this case, let's independently construct the corresponding concept, taking into account the above results of a structural analysis of the concept of «adaptive management» and from the perspective of a system-activity approach in the context of determining the system characteristics of such a management as a process (activity).

First of all, in the well-known definitions of the «adaptive management» concept, the common element, which is present in most of them explicitly or can be traced by the similarity of content, has the element of «change». The latter means the transformation, replacement of something, etc. [12] and is considered by scientists as a starting point in management. However, research only on the accuracy of measured changes in processes and phenomena misses the importance of accuracy in determining (measuring) their state at a certain point in time (initial, final, etc.).

In this regard, it is assumed that the initial moment in adaptive control should be the establishment of a signal about the state of the control object, since the term «signal» has a managerial context [12]. In the studied subject area, it can be defined as follows. A signal is a value of an indicator that reflects the characteristics of human capital and the state of its reproduction and which serves as information for its subsequent identification for the development of managerial decisions and the transfer of a team for their implementation. Signals should be established through the measurement procedure, during which a description of the process of human capital reproduction of industrial enterprises is formalized and the numbers and values of the corresponding indicators are established.

It is advisable to consider the «change» element in two ways: through changing economic conditions and through changing elements of the system for managing the human capital reproduction in industrial enterprises. The first is about the deviations recorded in a certain way in the values of the parameters that determine the factors of the general environment for the economic activity of industrial enterprises that affect the conditions, tasks and results of the human capital reproduction. In the second case, let's have established deviations in the characteristics of human capital due to the action of factors of the general environment and the consequences of its reproduction to ensure the socio-economic development of enterprises and the content of a competitive position will be determined.

Changes will be determined through the procedure for evaluating human capital and the effectiveness of managing its reproduction, which is implemented by comparing the measurement results with various approaches, criteria and the like. As a result of the assessment, the iden- tification of signals in relation to the characteristics of human capital and the state of its reproduction occurs, the main sources of reproduction and the consequences for the development of enterprises are determined. After the changes, the correspondence of the process of human capital reproduction to the environmental factors of the industrial enterprises as the environment of the conditions and tasks of this process is identified, its compliance with the goals of the development of enterprises is established, the potential of reproduction is determined.

The next important element that should be included in the understanding of adaptive management of the human capital reproduction of industrial enterprises and which is found in many definitions of adaptive management in general is the management cycle. In general terms, it is characterized as «a set of managerial actions ... that ensure the achievement of the goal of managerial activity» [12].

Many scientists consider the management cycle as an ordered set of functions. They agree that the main management functions should be considered as follows: planning, organization, motivation and control, which act as separate types of professional activity [30, 31].

In the context of this study, let's agree with the opinion of the author of [32], the management cycle was divided into the following stages: measurement, evaluation, planning and control. In such a sequence, information on the state of the object of research is first prepared, then it is compared with established norms, the results of the comparison determine the problems of managing, in the future they serve as the basis for the development of plans and their control. Such a vision of the management cycle operates with the main functions, which are planning and control, the implementation of which is aggravated by the measurement and evaluation operations, which are distinguished as independent stages. In these conditions, there is no neglect of the functions of organization and motivation, which are considered as those that ensure the implementation of planned tasks.

On this basis, let's consider it expedient to determine the management cycle in the system of adaptive management of the human capital reproduction of industrial consumer goods in an early manner. It is a set of managerial actions, consistently characterizes the receipt of signals about the characteristics of human capital and the state of its reproduction, their identification with the determination of the sources of education and consequences, the use of identification results to determine goals, objectives and means of appropriate changes in reproduction and to provide support for the implementation of planned actions and monitoring changes. Moreover, the stages of such a management cycle and the content of their tasks should be presented as follows:

Stage 1. Measurement of human capital and its reproduction: the establishment of signals regarding the characteristics of human capital and the state of its reproduction.

Stage 2. Assessment of human capital and the effectiveness of its reproduction management: identification of signals, determination of the sources of their formation and consequences.

Stage 3. Planning the directions of transformation of the processes of human capital reproduction: the goal, objectives and means of appropriate changes in the reproduction of elements of human capital.

Stage 4. Monitoring the human capital reproduction and monitoring the environment of its tasks: supporting the implementation of planned actions and monitoring changes. 
The final element of the concept of «adaptive management of the human capital reproduction of industrial enterprises» is the result of this process. Based on a common understanding of the term «result» as «the final, final result of any activity, development, etc.» [33] and a predefined set of adaptation results, the concept of the result of the investigated management process was formed. It is defined as the final result of the reproduction process, which is characterized by a cumulative transformation of the characteristics of human capital, which ensures the solution of the strategic problems of the effective functioning of industrial enterprises aimed at achieving them the actual economic goals and human development goals.

The result of constructing the concept of «adaptive management of the human capital reproduction of industrial enterprises», in which its basic elements and the substantial context of the corresponding management system are integrated, is presented in Fig. 1.

The logical result in the study of the complex of conceptual aspects of constructing a model of adaptive management of the human capital reproduction of industrial enterprises is its formalization (Fig. 2).

Presented in Fig. 2 conceptual model visualizes an integrated approach to the definition of the concept of «adaptive management of the human capital reproduction of industrial enterprises» and reflects the general configuration of the management cycle, constructed by the stages of measuring and evaluating human capital and the process of its reproduction, planning directions of transformation and control of the reproduction process while monitoring external environment.

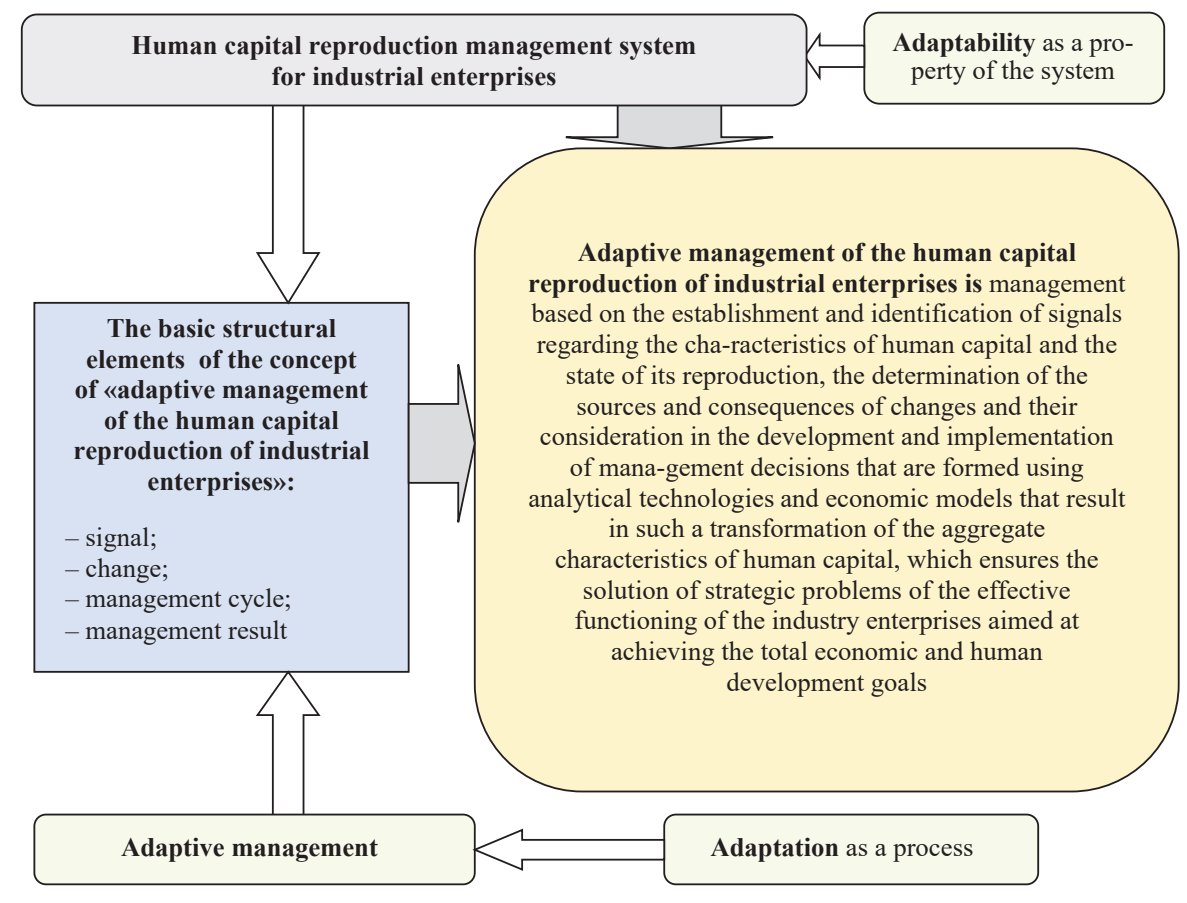

Fig. 1. An integrated approach to the definition of «adaptive management of the human capital reproduction of industrial enterprises»

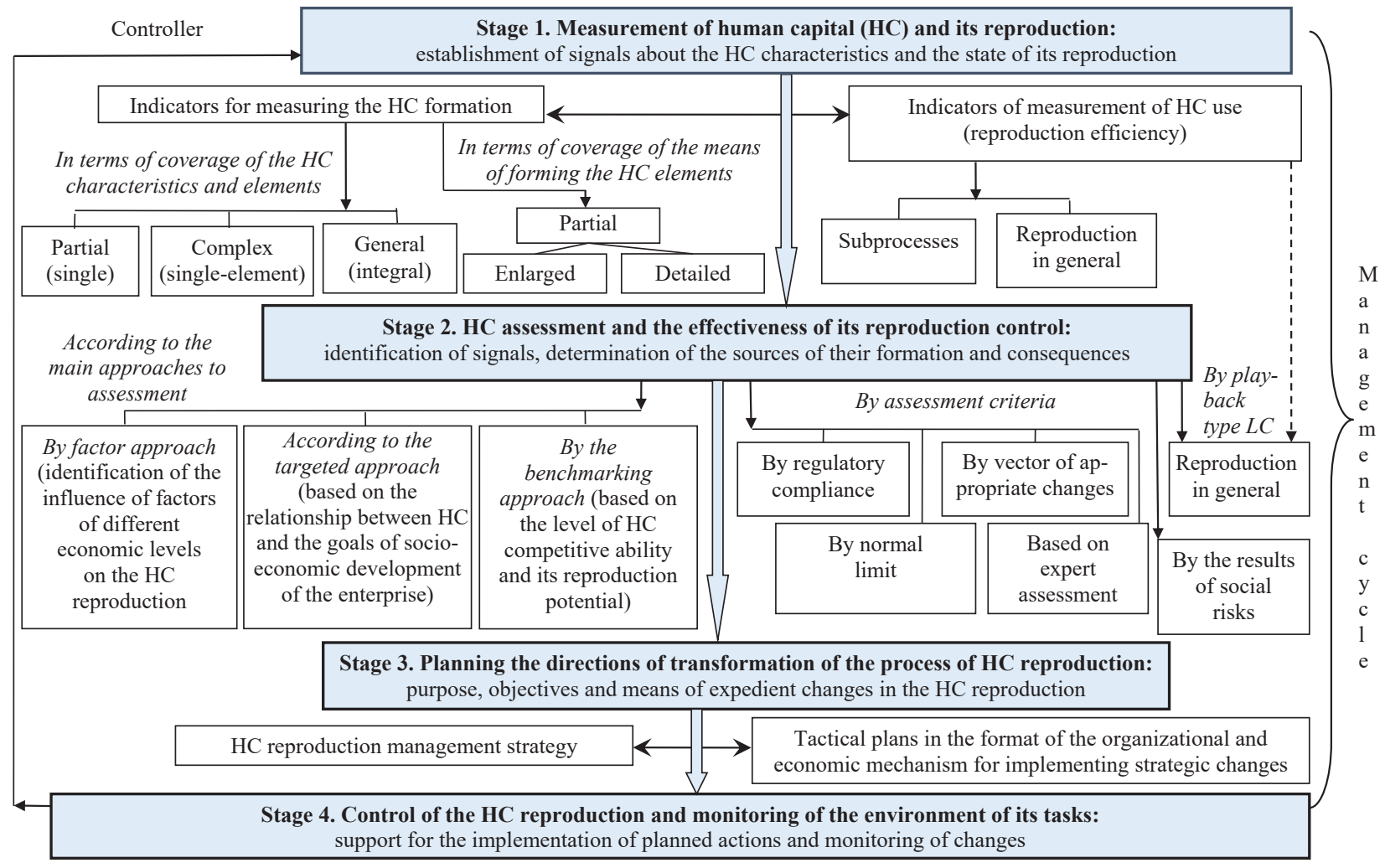

Fig. 2. Scheme of the conceptual model of adaptive management of human capital reproduction of industrial enterprises 
Moreover, the last stage is implemented through the control regulator, collects output signals for the subsequent adaptive response of the system to environmental changes and, at the same time, the development of preventive actions to achieve the development goals. Such a reaction can become quick and targeted only in case of combined application of the main approaches to enterprise management, provided for in the current model through the implementation of a set of analytical approaches and the use of a system of indicators.

Thus, the developed model provides a general formal idea of the structure of intrasystem functional relationships that act as channels for collecting and transmitting management information, a list of the main tasks for the management subject, the sequence of their solutions, methodological approaches, and expected results.

Based on a formal assessment of the structure and logic of building the model, its compliance with the essential properties and relationships of the management system for the human capital reproduction of industrial enterprises, the characteristics of adaptation and adaptive management, as well as on the basis of the problem field of the studied subject area, which is evidence of sufficient accuracy and at the same time extreme simplicity and visibility of the conceptual model, we conclude about its verification.

\section{SWOT analysis of research results}

Strengths. Strengths are:

- formation of a new subject area for the scientific study of adaptive management of the human capital reproduction that in the context of the formation of an innovative economy in the country is a promising task for the development of the theory of human capital; - focus of the study on the course of the reproduction process in the sector of the national economy, which is characterized by the presence of deep and long-term problems of the formation and use of human capital; - presentation of the conceptual model of adaptive management of the human capital reproduction of industrial enterprises in the format of specific tasks of a single management cycle with the definition of the sequence of their solutions and the main methodological approaches.

Unlike similar well-known models, the proposed format creates the basis for determining adequate directions of transformation of the reproduction process.

Weaknesses. Weaknesses are:

- increase in the complexity of management operations at the stages of measuring and evaluating human capital, the state of its reproduction and the effectiveness of its management. However, in the conditions of proper organization of information and application software this does not pose a significant threat to a quick reaction to changes in the business environment;

- feasibility of additional coordination of the activities of specialized units, whose functions are associated with the processes of formation in accordance with the capital of education, motivation, health, mobility and culture. The solution to this problem is supposed to be based on the creation of a single coordination center for the implementation of the full range of tasks for managing the human capital reproduction;
- increase in the cost of the reproduction management process, which is associated simultaneously with an increase in the complexity of management operations and the creation of a focal point. At the same time, an accelerated growth in the result of reproduction is predicted compared with an increase in the volume of necessary investments, which is a manifestation of the effect of the implementation of adaptive processes.

Opportunities. In the presented format, the conceptual model is at the same time a reflection of the plan for further scientific research, which contains key tasks to overcome the problematic issues of adaptive management of the human capital reproduction of industrial enterprises. These issues are identified by the structure of the management cycle and their solution requires further validation of such a model.

The practical implementation of the developed proposals allows to provide a quick and targeted response of enterprises to changes in the business environment regarding the adjustment of the characteristics of human capital.

The research results may be of interest to business entities of various types of economic activity and at different economic levels of government, including the development of programs for the development of human capital of the country, its individual regions, and international cooperation.

Threats. Threats in the implementation of research results may come from the external and internal business environment of Ukrainian industrial enterprises and may constitute problems during the process of reproduction of their human capital. Let's associate the greatest dangers with the presence of a conflict of interests between enterprise stakeholders, in which management decisions related to investments in human capital will be significantly inhibited.

\section{Conclusions}

1. Taking into account the significant scientific interest in the problems of adaptive management of enterprises and at the same time the lack of relevant research in the field of human capital reproduction management, the problem of determining the concept of «adaptive management of the human capital reproduction of industrial enterprises» is solved. It is defined as management based on the establishment and identification of signals regarding the characteristics of human capital and the state of its reproduction, the determination of the sources and consequences of changes and their consideration in the development and implementation of management decisions. These decisions are formed using analytical technologies and economic models and the result of which is such a transformation of the aggregate characteristics of human capital, which ensures the solution of the strategic problems of the effective functioning of industrial enterprises aimed at achieving relevant economic and human development goals.

2. The scheme of the conceptual model of adaptive management of the human capital reproduction of industrial enterprises is formed. It is based on a compromise concept, which determines the objective possibilities of applying in this subject area a combination of the basic provisions of the main modern approaches to the management of food acceptance, as well as solving a set of scientific tasks to adapt the management system for the human capital reproduction in a dynamic and changing development of industrial enterprises. 
The model reflects the general configuration of the managerial cycle, built on the stages of measuring and evaluating human capital and the process of its reproduction, planning the directions of transformation and control of the reproduction process with simultaneous monitoring of the external environment. Its use in enterprise management is aimed at determining the internal systemic relationships, the range of tasks, the sequence of their solutions, the tools for preparing and making decisions, and the expected results.

3. Based on a formal assessment of the structure and logic of building the model, its essential properties and relationships, it is concluded that the model is verified. This is evidence that the model accurately reflects the specifics of the process of human capital reproduction, the logic in the course of the management cycle, is at the same time simple and intuitive.

\section{References}

1. Ofitsiinyi sait Derzhavnoi sluzhby statystyky Ukrainy. Available at: http://www.ukrstat.gov.ua Last accessed: 15.06.2019

2. Bogatyireva, V. V. (2013). Finansovoe upravlenie vosproizvodstvom chelovecheskogo kapitala v innovatsionnoy ekonomike: teoriya, metodologiya, modelirovanie. Novopolotsk: PGU, 400

3. Nikolaichuk, M. (2012). Zasady ta pryntsypy upravlinnia vidtvorenniam liudskoho kapitalu. Ekonomichnyi analiz, 10 (1), 428-432.

4. Gaysina, L. M. (2015). Adatitivnoe upravlenie v usloviyah sotsialnyih peremen. Sovremennyie problemy $i$ nauki $i$ obrazovaniya, 1 (1). Available at: http://www.science-education. $\mathrm{ru} / \mathrm{ru} /$ article/view?id=19583 Last accessed: 18.06.2019

5. Lawrence, P. R., Lorsch, J. W. (1986). Organization and Environment. Boston: Harvard Business School Press, 279.

6. Thompson, J. D. (2003). Organizations in Action: Social Science Bases of Administrative Theory. New Brunswick, New Jersey: Transaction, 222

7. Carroll, G. R. (1985). Concentration and Specialization: Dynamics of Niche Width in Populations of Organizations. American Journal of Sociology, 90 (6), 1262-1283. doi: http://doi.org/ $10.1086 / 228210$

8. Hannan, M. T., Freeman, J. (1989). Organizational Ecology. Cambridge: Harvard Univ. Press, 384. doi: http://doi.org/10.2307/ j.ctvjz813k

9. Starikova, M. S. (2015). Teoriya i metodologiya adaptionogo upravleniya promyishlennoy korporatsiey na osnove effektivnyih delovyih vzaimodeystviy. Belgorod, 46.

10. March, J. G., Olsen, J. P. (1976). Ambiguity and choice in organizations. Bergen: Universitetsforlaget, 408.

11. Weick, K. (1985). Sources of order in underorganized systems: Themes in recent organizational theory. Organizational Theory and Inquiry: The Paradigm Revolution. Beverly Hills, 106-136.

12. Slovari $i$ entsiklopedii na Akademike. Available at: http://dic. academic.ru Last accessed: 21.06.2019

13. Voloshyna, S. V. (2019). Vidtvorennia liudskoho kapitalu pidpryiemstva ta yoho vlastyvosti. Visnyk Donetskoho natsionalnoho universytetu ekonomiky $i$ torhivli imeni Mykhaila TuhanBaranozskoho. Seriia «Ekonomichni nauky», 1 (70), 105-120.
14. Voloshyna, S. V. (2019). Systema upravlinnia vidtvorenniam liudskoho kapitalu pidpryiemstva. Prychornomorski ekonomichni studii, 42, 69-76.

15. Akoff, R. (2002). Akoff o menedjmente. Saint Petersburg: Piter, 448

16. Daft, R. L., Lane, P. (2010). Management. South-Western Cengage Learning, 699.

17. Nelson, D. R., Adger, W. N., Brown, K. (2007). Adaptation to Environmental Change: Contributions of a Resilience Framework Annual Review of Environment and Resources, 32 (1), 395-419. doi: http://doi.org/10.1146/annurev.energy.32.051807.090348

18. Galkina, N. V., Korkina, T. O., Ustinova, S. A. (2007). Formalizatsiya protsessa sotsialno-ekonomicheskoy adaptatsii ugledobyivayuschego predpriyatiya $\mathrm{k}$ innovatsionnomu tehnologicheskomu razvitiyu. Gornyiy informatsionno-analiticheskiy byuleten, 391-399. Available at: https://cyberleninka.ru/article/v/ Last accessed: 19.06.2019

19. Brauning, P. (1987). Sovremennyie ekonomicheskie teorii. Moscow: Ekonomika, 342.

20. Nahorianska, N. V. (2009). Upravlinnia efektyonoiu adaptatsiieiu promyslovoho pidpryiemstva do zmin rynkovoho seredovyshcha. Mariupol, 20.

21. Ansoff, I. (1999). Novaya korporativnaya strategiya. SanktPeterburg: Izdatelstvo «Piter», 416.

22. Boiarynova, K. O., Voitun, T. V. (2013). Naukovi pidkhody ta determinanty zabezpechennia innovatsiinoi adaptyvnosti promyslovoho pidpryiemstva. Ekonomichnyi analiz, 14 (2), 111-116.

23. Grinko, T. V. (2010). Kontseptsiya adaptivnogo upravleniya innovatsionnyim razvitiem promyishlennogo predpriyatiya. Ekonomika promyslovosti, 4, 113-119.

24. Druker, P. (2008), Effektivnoe upravlenie. Moscow: Vilyams, 224.

25. Efendiev, B. A. (2008). Razrabotka i funktsionirovanie adaptivnyih sistem upravleniya organizatsiey. Rossiyskoe predprinimatelstoo, 11-2 (122), 21-25.

26. Bagrinovskiy, K. A. (1999). O metodah adaptivnogo upravleniya v perehodnoy ekonomike. Ekonomicheskaya nauka sovremennoy Rossii, 2, 30-39.

27. Tihomirova, O. G. (2012). Adaptivnoe upravlenie predprinimatelskimi strukturami kak otkryityimi dinamicheskimi sistemami. Fundamentalnyie issledovaniya. Ekonomicheskie nauki, 9 (2), 495-499.

28. Zhdamirov, Ye. Iu. (2010). Sutnist adaptatsii upravlinnia funktsionuvanniam pidpryiemstv. Visnyk Sumskoho natsionalnoho ahrarnoho un-tu. Seriia «Ekonomika i menedzhment», 6(1 (41)), 93-101.

29. Tsibizov, A. A. (2009). Informatsionnaya komponenta protsessa adaptivnogo upravleniya sovremennogo predpriyatiya. Izvestiya KBNTS RAN, 3 (29), 34-39.

30. Meskon, M., Albert, M., Hedouri, F. (2019). Osnovyi menedzmenta. Moscow: Dialektika-Vilyams, 672.

31. Khmil, F. I. (2003). Osnovy menedzhmentu. Kyiv: Akademvydav, 608.

32. Sink, D. S. (1989). Upravlenie proizvoditelnostyu: planirovanie, izmerenie i otsenka, kontrol i povyishenie. Moscow: Progress, 528.

33. Akademichnyi tlumachnyi slovnyk. Available at: http://sum.in.ua/ s/socialjnyj Last accessed: 08.06.2019

Voloshyna Svitlana, PhD, Associate Professor, Department of Entrepreneurship and Trade, Donetsk National University of Economics and Tradenamed after Mykhayilo Tugan-Baranovsky, Kryvyi Rih, Ukraine, e-mail: voloshyna@donnuet.edu.ua, ORCID: http:// orcid.org/0000-0001-7148-6923 